\title{
Democratization
}

\section{Islam and democratization in Turkey: secularism and trust in a divided society}

\section{loannis N. Grigoriadis}

To cite this article: Ioannis N. Grigoriadis (2009) Islam and democratization in Turkey: secularism and trust in a divided society, Democratization, 16:6, 1194-1213, DOI: $10.1080 / 13510340903271803$

To link to this article: https://doi.org/10.1080/13510340903271803

曲 Published online: 06 Nov 2009.

Submit your article to this journal $\pi$

III Article views: 2123

7 Citing articles: 18 View citing articles ๘ 


\title{
Islam and democratization in Turkey: secularism and trust in a divided society
}

\author{
Ioannis N. Grigoriadis* \\ Bilkent University, Ankara, Turkey \\ (Received April 2009; final version received August 2009)
}

The history of Turkish modernization has been inextricably linked with the question of secularism. From the advent of the Turkish Republic in 1923, Islam was held responsible for the underdevelopment and eventual demise of the Ottoman Empire. Based on the laïcité of the Second French Republic, the secularization programme of modern Turkey's founder, Kemal Atatürk, entailed the full subjugation of Islam to the State, its eradication from the public sphere and its limitation into a very narrowly defined private sphere.

The transition of Turkey to multiparty politics in 1946 was linked with a rising role of Islam in the public sphere. Islam became a crucial element in the political vocabulary of peripheral political forces which challenged the supremacy of the secularist, Kemalist bureaucratic elite. While a number of military coups aimed - among other things - to control religion, Turkish political Islam showed remarkable resilience and adaptability.

Most recently, the transformation of the Justice and Development Party (Adalet ve Kalkinma Partisi - AKP) into the strongest proponent of Turkey's European Union (EU) integration brought Turkey closer than ever to EU membership, challenged the monopoly which the Kemalist elite enjoyed as the representative of Western political values and suggested a novel liberal version of secularism. Yet Turkey has been embroiled since 2007 in successive political crises which had secularism as their focal point. This article argues that the transformation of Turkish political Islam has produced an alternative, liberal version of secularism; yet, it has not resolved deep social divisions. Building a liberal consensus between religious conservatives and secularists is imperative for the resolution of deep social divisions in Turkey. The European Union as a guarantor and initiator of reform could play a major role in building trust between the secularist and the religious conservative segments of society.

Keywords: Islam; democracy; Turkey; secularism; democratization; liberalism

*Email: ioannis@bilkent.edu.tr 
In December 2007, Fazıl Say, a famous young Turkish pianist who after a shining international career decided to move back to Turkey in 2002 was interviewed by a German newspaper, Süddeutsche Zeitung. His remarks caused a controversy, as Say, speaking on behalf of the country's secularist elite touched upon a very sensitive issue: secularism in Turkey. The young artist said that he considered emigrating from Turkey due to the rise of Islamism in the country. In his own words:

Our dreams are somewhat dead in Turkey. All ministers' wives wear headscarf. I want to move somewhere else ... I am waiting for the dialogue of the counter part for six years. There are some things that annoy me ... Turkey's music lover characteristic is being destroyed. ${ }^{1}$

Say's remarks caused a media sensation in Turkey. One of the most charismatic young Turkish artists, already acclaimed in Europe, who had returned to the country in 2004, at the peak of optimism about the country's European Union (EU) membership, was announcing his intention to emigrate for political reasons. His statement prompted various reactions from the ranks of the government party, the AKP. Prime Minister Recep Tayyip Erdoğan commented that 'the artists of this country do not abandon it'. Minister of Culture Ertuğrul Günay responded that 'His concerns are not founded. I do not understand his concerns about the future of Turkey, either.' ${ }^{2}$ However, the bitterest reaction came from the Vice President of the AKP, Dengir Mir Mehmet Firat, who said: 'Mr. Say is free to do so [emigrate]. I respect that and do not feel much sadness.' One of the most interesting responses came from another renowned Turkish artist. Fashion designer Cemil İpekçi commented on Say's statement in an interview to the liberal Islamist newspaper Zaman as follows:

I know Fazıl Say; he is a very nice person. But what does this 'those' mean? Those he calls 'those' get 70 percent of the vote. How does he make this division? These are the white Turks, 40,000 people to whom my family also belongs, who think that Turkey consists of Nişantaşı ${ }^{4}$ They do not see a Turkey of 65 million people, because these are the last outcries of a specific minority and dinosaurs. ${ }^{5}$

Say's reaction was however characteristic of a wider trend in Turkish society. The issue of secularism became increasingly pronounced in 2007, as the political dominance of the post-Islamist AKP raised concerns among Turkey's secularist elite regarding the future trajectory of the country. The year 2008 was marked by a closure case against the AKP filed by the country's chief prosecutor Abdurrahman Yalçınkaya. In the case it was claimed that the party had become a 'centre of antisecular activities' threatening the republican nature of the Turkish state. While the court decision accepted the argument of the prosecutor, it fell short of closing the party. ${ }^{6}$

In fact, secularism has been a key political theme since the early twentieth century. The demise of the Ottoman Empire and the rise of republican Turkey were linked with a radical shift from pan-Islamism towards secularization. 
Based on the secularism of the Second French Republic, the secularization programme of Kemal Atatürk entailed the full subjugation of Islam to the state, its eradication from the public sphere and its limitation into a very narrowly defined private space. This came under challenge with the rise of political Islam and an Islamist elite which challenged the supremacy of senior Kemalist figures, won political power by democratic means and suggested an alternative version of secularism, which did not oppose a public role for religion.

The summer 2007 presidential crisis ${ }^{7}$ was illustrative of the relevance of this conflict to contemporary political developments. This article aims to explore the question of secularism in Turkey in light of recent developments in Turkish politics and society. It attempts to define the term 'secularism' and questions the consensus view that Turkey is indeed a secular state. It also explores different conceptualizations of secularism which lie at the heart of the contemporary debate in Turkey and are linked to a significant degree to the impact of globalization on Turkish society. It then examines the transformation of Turkish political Islam, its limits and evaluates the new version of secularism which the incumbent AKP government advocates. Amidst rising social tension, mutual distrust has aggravated relations between secularists and conservatives, as both sides have become caught in a vicious circle of claim and counter-claim regarding their motivations and goals. This article argues that an external actor with bearing on both factions such as the EU may indeed be instrumental in alleviating mutual distrust and helping build toleration for different lifestyles in Turkey.

\section{Is Turkey a secular state?}

Republican Turkey is often described as the 'only Muslim secular state', a 'model for the Islamic world'. Nonetheless, a closer examination of the term 'secular' reveals that this description is inaccurate. ${ }^{8}$ The meaning of the term 'secular', colloquially understood as 'non-religious', is not limited to the separation of religious and political realms in Turkey. Instead, it involves a neutral stance toward different religious beliefs, as well as the phenomenon of religion in general. A genuinely secular state has no preferential links with any religion and neither promotes, nor obstructs religious belief among its citizens. The republican Turkish state fulfils neither of these conditions. Opposition to any religious form of expression within a - widely defined - public sphere shows the traditionally hostile approach of the Turkish state toward religion. For example, the ban on Islamic religious orders (tarikat) and religious attire, the headscarf issue and the eradication of religion from the public sphere are all indicative of a state which has long taken aggressive measures to put religious institutions under its firm control and promote a 'religion-free', 'rational' society. Religion was expected to fade away as a result of the consequential 'enlightenment' and 'modernization' of Turkish society and the associated upward economic and social mobility of its citizens. ${ }^{9}$ As a result, the term 'assertive secularism' - rather than 'secularism' per se - more accurately describes state-religion relations in republican Turkey. ${ }^{10}$ Nevertheless, the 
assertively secular character of the Turkish state has often been compromised as a result of political expediency. This compromise was not in the direction of original secularism, but rather toward championing a certain form of state religion.

Secular-ideological opposition to religion did not mean lack of state interest in the instrumental use of religion for political purposes. Sunni Islam, as a cementing factor of Turkish national identity and a counterweight to the perceived divisive influence of ethnic minority nationalism and leftist ideas, has been skilfully used since the founding years of the Republic; this also contradicted with the principle of secularism. ${ }^{11}$ While Islam was purged from the public sphere in the early republican period, the state kept a firm control over it by banning the tarikats and establishing the Directorate of Religious Affairs (Diyanet Işleri Başkanliğl - DİB). ${ }^{12}$ Active intervention and control was viewed as the only means to secure the containment of the perceived threat from political Islam to the state's secular ideals and goals. This policy shift became institutionalized with the official championing by the 1980-1983 military regime of what was known as the 'Turkish-Islamic Synthesis' (Türk-Íslam Sentezi), the introduction of mandatory religious primary education and clauses in the 1982 Constitution which strengthened the power of Sunni Islam. ${ }^{13}$ The pro-Sunni bias evident in the policies of the Directorate of Religious Affairs, the mandatory instruction of Sunni Islam in state schools and the state-funded construction of mosques throughout the country - even in Alevi ${ }^{14}$ villages - comprised clear manifestations of a pervasive bias in favour of Sunni Islam. ${ }^{15}$ Especially when it came to the Alevi question, the assertively secular Turkish state suddenly became a Sunni one. ${ }^{16}$

This mixed legacy of animosity toward religion, state control and bias in favour of Sunni Islam forms the framework of state-society relations in republican Turkey. Turkey could, therefore, be characterized as a sui generis assertively secular state, in which long-term antireligious policies are matched by shortterm instrumental use of Sunni Islam. ${ }^{17}$ This situation created a serious obstacle in the process of Turkey's democratization, facilitated the politicization of Islam, and created an environment conducive to political conflict. ${ }^{18}$

\section{The transformation of Turkish political Islam}

The 'soft' coup of 28 February 1997 and the subsequent fall of the coalition government led by the Islamist Necmettin Erbakan crucially affected the course of political Islam in Turkey. At the domestic level, it became clear that any ideas about regime change and the introduction of the Islamic law were utterly unrealistic. This was due not only to the reaffirmation of the guardian role of the military in Turkish politics, but also to the lack of appeal of any Islamization programme to the vast majority of the people. ${ }^{19}$ If a party with an Islamist political character could ever manage to claim a leading role in Turkish politics, this could only happen through its transformation into a conservative centre-right party with Islamic leanings. ${ }^{20}$

At the European level, the 2001 decision of the European Court of Human Rights (ECHR) to uphold the decision of the Turkish Constitutional Court on 
the closure of the Islam-leaning Welfare Party (Refah Partisi - RP) was a milestone event. On the one hand, Erbakan's decision to appeal to the ECHR against the closure of the RP undermined his rhetoric against European institutions and civilization. The establishment of an Islamic 'just order' in Turkey, which had been the perennial quest of the National View (Milli Görüş) movement, ${ }^{21}$ implied the moral supremacy of the Islamic civilization over the European. ${ }^{22}$ By appealing to the European Convention of Human Rights (ECHR), Erbakan tacitly acknowledged that 'Christian Europe' was an alternative and acceptable source of justice. The relativization of the concept of Islamic justice by the very person who had fought throughout his life for its establishment in Turkey undermined any belief in the superiority of Islamic civilization and showed that the Islamist political project in Turkey had reached its limits. The court ruled that, by closing the RP, the Turkish court did not violate Article 11 of the ECHR. The court held in July 2001 that

the sanctions imposed on the applicants could reasonably be considered to meet a
pressing social need for the protection of democratic society, since, on the pretext
of giving a different meaning to the principle of secularism, the leaders of the
Refah Partisi had declared their intention to establish a plurality of legal systems
based on differences in religious belief, to institute Islamic law (the Sharia), a
system of law that was in marked contrast to the values embodied in the Convention.
They had also left in doubt their position regarding recourse to force in order to
come to power and, more particularly, to retain power. ${ }^{23}$

This decision, which was made by the Third Section of the ECHR, was firmly upheld by the ECHR Grand Chamber in February 2003. ${ }^{24}$ The ECHR decision demonstrated that Islamic extremism could not be protected by European liberal democratic institutions. Support of European political institutions for Turkish political parties under state persecution was not unconditional. Turkish political parties had to subscribe to European political values to be then able to claim European support. Like terrorism, Islamic fundamentalism or even traditional political Islam could not expect support from European courts. ${ }^{25}$ The threat which 'Islamic fundamentalism' constituted for democratic principles and human rights was not underestimated, and the misuse of democratic institutions for undemocratic objectives could not be endorsed by European institutions

In the aftermath of the RP closure, ideological debate within the Virtue Party (Fazilet Partisi - FP), the party which succeeded RP as the representative of Turkish political Islam, showed a radical ongoing transformation. Many of its members attempted to break the vicious circle of state suppression by advocating a radical transformation of Islamist ideology. The establishment of an Islamic republic would no more be the ultimate aim. Allegiance to the secular principles of Western European democracy was instead adopted, and an amalgamation of Islamic values with Western political liberalism was attempted. ${ }^{26}$ The quest for Islamic religious freedoms was now framed in the language of political liberalism and multiculturalism. Crucial for the rehabilitation of the hitherto Western image of 
'corruption' was the experience of immigration to Western Europe for millions of Turkish citizens, who realized that they could more freely practice Islam in 'Christian' Germany than in 'Muslim' Turkey. The German legal order lacked the restrictions in the manifestation of Islamic religious belief in the public sphere, which hampered Islamic religious freedom in Turkey. ${ }^{27}$

This ideological trend within the Islamist intelligentsia obtained a political vehicle with the formation of the Justice and Development Party (Adalet ve Kalkinma Partisi - AKP) in the aftermath of the closure of the FP in 2001. The AKP leadership took pains to dissociate the new party from its Islamist past, and advertised itself as a moderate conservative party, ${ }^{28}$ loyal to secularism. ${ }^{29}$ The new ideology of the party was an amalgam of conservativism, liberalism, Islamic values and rightist political ideas. The term 'Islamist' was rejected as a description of the ideological identity of the party; the term 'conservative democratic' (muhafazakâr demokrat) was preferred. ${ }^{30}$ The AKP was the first party from the Islamic political tradition to address the grievances of Turkey's pious Muslim population not in terms of Islamic justice or 'just order' (adil düzen), but on the basis of a liberal and human rights agenda. The assertively secular character of the Turkish state was criticized, not from an Islamist but from a liberal perspective. Contested issues of major symbolic importance, like the headscarf and religious education, were now discussed as evidence of Turkey's democratic deficit. The liberal shift of the AKP was confirmed when - contrary to the tradition of the National View parties - it ardently supported Turkey's bid for EU membership.

The November 2002 elections became the big test case for the AKP political experiment: With $34.43 \%$ of the vote and 365 parliamentary seats the AKP formed a single-party government, while the traditionalist Islamic Felicity Party (Saadet Partisi - SP) gained only 2.49\% and no seats. The AKP had succeeded in winning power, dominating the political agenda and ideology of Turkish political Islam and opening it to the influence of Western political ideas. The emphasis on Islamic morality as an antidote to chronic political corruption remained, ${ }^{31}$ but the political priorities of the new government were different. After taking over power, the AKP and its leader Recep Tayyip Erdoğan vowed to pursue the reform steps necessary for Turkey to qualify for the start of EU accession negotiations. The prospect of EU membership provided a vision, which the majority of Turkish society shared. ${ }^{32}$ The AKP leadership realized that the European Union could be of critical help in its effort to gain political legitimacy ${ }^{33}$ and promote the sensitive, religion-related aspects of its political agenda. By becoming an ardent supporter and promoter of Turkey's EU membership, the AKP leadership challenged the monopoly of Kemalist elites in their advocacy of Westernization and EU membership. Raising the level of human rights protection in Turkey to the European standards fell within the scope of fulfilling the Copenhagen Criteria for the start of EU accession negotiations, and created the conditions for their successful completion. The reform of Turkey's human rights legislation would necessarily mean a redefinition of the public and private spheres in Turkish society. Many activities which would - until the reform - fall within 
the scope of the public realm, would now be transferred to the private realm and thus enjoy full protection under the new human rights legislation. ${ }^{34}$ The prospect of EU membership and the EU monitoring of Turkish politics also provided a secure environment against any intervention by military and bureaucratic elites. This enabled the AKP government to implement its reformist political programme, which confirmed the transformation of the AKP from an Islamist to a conservative democratic party, ${ }^{35}$ increasingly similar to the equivalent religious value-based Christian Democratic parties of Western Europe.

\section{A new version of secularism in the making?}

While Europe affirmed its opposition to Islamic fundamentalism by refusing to provide protection to the RP and Turkish political Islam was transformed, the question of how to protect freedom of religion against state practices remained open. Turkish political Islam traditionally viewed the secularist character of the Turkish state as a dire consequence of the Kemalist Westernization project. Europe was the historic cradle of assertive secularism and as such responsible for the antireligious character of the Turkish Republic. Nonetheless, with the rise of the AKP, Islamist intellectuals and politicians, alternative Western systems of regulating state-religion relations were explored. The fact that the AKP abandoned the Islamic state project for the sake of Western liberal democratic principles did not mean that it lost its sensitivity on issues of religious freedom; its argument, however, was now based upon political liberalism. ${ }^{36}$ The establishment of a pluralist public sphere in Turkey was now suggested as the solution for the problems related to the public visibility of Islamic identity in Turkey. ${ }^{37}$ This could be the starting point for the reform of Turkish secularism. This was inspired by French laïcite of the Second French Republic, the most antireligious system in the Western world and hardly compatible with the principles of Western European liberal democracy. It was, therefore, possible to argue for a reform of Turkish assertive secularism not on the basis of restoring Islamic law, but rather of introducing liberal principles. ${ }^{38}$ This reform would aim at substituting a truly secular, religionblind policy for the antireligious character of state policies as well as the bias in favour of Sunni Islam. This model of 'passive secularism' would be distanced from the French model of laïcité and could be more closely related to the United Kingdom or German models of secularism and Western European liberal standards. ${ }^{39}$ It would protect state and religion from mutual interventions and protect Turkish democracy without obstructing the free religious expression of the majority of the Turkish people. In a treatise, which appeared on the official AKP website and could thus be considered to reflect the party's official views, Akdoğan, a scholar affiliated with the AKP, argued:

The AKP understands 'secularism' ${ }^{, 40}$ as an institutional stance and method, which ensures that the state remains neutral and keeps an equal distance from all religions and ideas; differences of religion and/or different confessions and ideologies can 
be professed in social peace without them turning into conflict. The party thinks that, for secularism to work as an adjudicating institution (hakem muessesi) of the fundamental rights and freedoms under constitutional protection, it needs to be supported by democracy and operate in a conciliatory environment. ${ }^{41}$

Thus, the AKP accepted secularism as 'an indispensable condition of democracy and the guarantee of the freedom of religion and conscience, ${ }^{42}$ while simultaneously linking it with democracy and human rights. This position attempted to reconcile the legacy of illiberal Turkish assertive secularism with respect for democratic principles and fundamental freedoms. Secularism should not mean the absence of religion from the public sphere, or the state control of religious institutions. The version of passive secularism that the AKP advocated did not eliminate religion from the public sphere, but required the state to adopt a neutral stance on religious issues and respect the freedoms of religion and conscience of its citizens. ${ }^{43}$ The re-emergence of religion in the public sphere should not, therefore, be seen as a reassertion of militant political Islam, but as maturation in the process of democratization and transition from assertive to passive secularism. The introduction of such a secular system would mean the simultaneous abolition of Kemalist assertive secularism and Islamism in favour of a liberal democratic solution. ${ }^{44}$ This became clear in the AKP political programme in 2004, where secularism was defined as an 'orienting principle for the state, but not for the individual', 'a means to freedom and social harmony' and 'a guarantee of freedom of conscience'. ${ }^{45}$

The appeal of this redefinition of secularism was not restricted to the leading circles of the AKP. Prominent Islamist intellectuals, who had once supported the establishment of an Islamic state in Turkey, became proponents of Turkey's European vocation. ${ }^{46}$ The European Union was no more the arch enemy, but a de facto ally in their struggle against the Kemalist secularism and its iron fist, the military. The reform of assertive secularism could be achieved through Turkey's democratization, which only the process of Turkey's EU accession could guarantee. While democracy and human rights had been despised as prime examples of Western concepts, which had adulterated sound Islamic political thought, they now occupied the centre of Islamist political discourse, ${ }^{47}$ offering a solution for the problem of secularism. The adoption of these principles of modernity resulted in a paradoxical situation whereby former Islamist intellectuals were defending human rights and democracy, pointing to the shortcomings of the Kemalist modernization project, which, despite professing modernity, had failed to deliver its proclaimed biggest blessings. ${ }^{48}$

\section{The headscarf issue}

The same liberal discourse was recently applied in a novel approach to the headscarf issue, one of the symbols of the secularist controversy in republican Turkey (also see Barras' article in this special issue). The ban on females' headscarf use in state institutions was one of the clearest manifestations of the assertively 
secular character of republican Turkey. The rise of an Islamic 'counter-elite' in the 1980s had resulted in the extreme politicization of the headscarf issue as the members of the new elite felt able to challenge the hegemony of the established secular elite. While retaining its original religious and traditional meaning, wearing the headscarf also achieved an explicitly political symbolic value. It became a political statement of a new rising and ambitious elite. Nonetheless, the argument in favour of females' headscarf use was still based on an Islamist discourse. The headscarf was understood as an indispensable element of female Islamic morality, and Islamic law failed to recognize the distinction between the public and the private sphere. The assertively secular principle of keeping religion outside the public sphere could not tolerate the most public manifestation of resistance to assertive secularism. The purge of the public sphere culminated in the aftermath of the 'soft' coup of 28 February 1997. The response to this campaign by the short-lived FP and, most importantly, the AKP, markedly differed in its content. Under the AKP, reference was made to the idea of 'universal human rights' embodied in international human rights conventions, and Islamic law was no more seen as the sole manifestation of justice. The right to education, the principle of non-discrimination, the freedom of religion as protected by the ECHR and other international human rights treaties were quoted in defence of the right of women to wear the headscarf. Even the solution suggested for the problem, based on a 'social consensus', ${ }^{49}$ was borrowed from Western liberal thought. ${ }^{50}$

This shift in the AKP discourse was not well received by everyone. Many secularists saw the headscarf question as a litmus test for the commitment of the AKP to republican ideals. Another segment of the republican elites persistently doubted the motives of the AKP government, accusing it of having a secret agenda for the Islamization of Turkish state and society. ${ }^{51}$ They argued that the AKP leadership could not have jettisoned its Islamist worldview within a few years. It was argued that it had actually been engaged in dissimulation (takiyye) by hiding its true intentions to establish an Islamic state, until the time was ripe. ${ }^{52}$ Although such arguments were rather exaggerated, they were sometimes supported by clumsy attempts by the AKP to appease the Islamist part of its electoral base. ${ }^{53}$

The rise of the AKP to power in November 2002 did not signal a break with past state policies on the headscarf issue. Despite the explicit expectations of its electoral base, the AKP government normally abstained from openly raising the headscarf issue, in an effort to avoid polarizing the political scene and antagonizing the military and bureaucratic elites. Instead it opted to wait for the imminent decision of the ECHR on the issue, which was hoped to relieve the government of the political cost of reforming the headscarf legislation. The decision of the ECHR, however, in the case of Leyla Şahin vs. Turkey did not help these plans. As Barras shows in her contribution to this special issue, the court ruled that there was no violation of Article 9 (freedom of thought, conscience and religion) of the ECHR when the applicant was denied access to university examination and enrolment, because she wore a headscarf. ${ }^{54}$ Although the ECHR decision 
did not help resolve the headscarf issue in Turkey, it had no profound impact on the liberal basis of the AKP public discourse. ${ }^{55}$ However, it may have been one of the reasons for weakening its zeal to pursue EU-driven reform, which suffered a severe deceleration after 2004.

The symbolic significance of the headscarf issue was confirmed once again, when it became the focus of the confrontation between the AKP government and the bureaucracy in 2007. The constitutional amendment annulled by the Constitutional Court was meant to resolve a problem which has grown far beyond its original dimensions and has underlined the inability of Turkey's society to reach a liberal consensus to accommodate its diversity.

\section{The Directorate of Religious Affairs}

The AKP showed less determination in applying the same liberal discourse in the

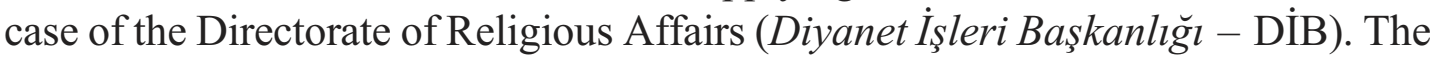
exponential growth of the activity of the Directorate since the 1980s has been one of the clearest indicators of the Islamist social and political resurgence. Its budget in 2007 was 38\% bigger than the budget of the Ministry of Interior, 2.3 times that of the Ministry of Foreign Affairs and twice that of the Ministry of Culture. ${ }^{56}$ Its personnel grew from 25,236 in 1970 to over 74,114 in 2004, while the number of mosques nearly doubled, from 42,744 in 1971 to 76,445 in $2004 .^{57}$ The expanding activity of the Directorate undermined the secular character of the Turkish state, given that it exclusively promoted Sunni Islam. Alevi associations and other religious minority representatives have repeatedly addressed their grievances about the Sunni bias of the Directorate and the absence of any funding programmes for Alevi religious houses of worship (cemevi). The reform of the Directorate was suggested by human rights organizations as a necessary step for the establishment of genuine secularism. Two possible solutions were suggested. The state should either cede control of the Directorate to the religious communities themselves, or maintain control of the Directorate, but guarantee the proportional representation of all religious groups in it, as well as their proportionate access to the Directory budgetary funds. ${ }^{58}$ The prospect of Turkey's EU membership brought the Directorate to public attention, as EU Commission reports noted its unequal treatment of religious groups. ${ }^{59}$ During the ensuing discussions on necessary reform steps, some human rights organizations suggested the transformation of the Directorate into an autonomous state authority, following the example of the Higher Education Council (Yüksek Ögretim Kurulu - YÖK). Other experts suggested the abolition of the Directorate and the takeover of its activities by the religious communities. Securing equal access of non-Sunni Muslims to the Directorate and its services was also underlined. ${ }^{60}$ While the implementation of these proposals could contribute to the elimination of the Sunni bias of the Directorate, the AKP government did not display the same energy that it had shown in advocating the free profession of the Islamic faith in public space. Occasional statements by AKP officials - including Prime Minister Erdoğan 
himself - on Alevi grievances regarding the Directorate did not convey the expected level of sensitivity and loyalty to liberal principles when it came to recognizing Alevis as a separate religious group and not just as a branch of Sunni Islam. ${ }^{61}$ It seems that the Sunni background of the AKP leadership has obstructed a liberal approach to the Directorate question, casting doubt about the depth of its liberal convictions. ${ }^{62}$ Nonetheless, the existence of a persistent debate on how to bring the Directorate's role and functions in line with liberal and secular ideas does provide evidence that, although the AKP has failed in this case to play the role of a reform catalyst, the introduction of a new secularism has become a key issue in the country's political agenda. ${ }^{63}$

\section{Secularism as the focal point of a major political crisis}

2007 was a tumultuous year in Turkish politics. Both presidential and parliamentary elections took place in the summer of that year in a very tense political atmosphere in which secularism was the key political issue. A crisis erupted on 24 April 2007, when Prime Minister Erdoğan announced his decision to support the candidacy of Foreign Minister Abdullah Gül for the office of the Republic's President. Secularist media and civil society objected to the candidacy on the grounds that it prepared the abolition of secularism and the very principles of the Republic. The fact that Gül's wife Hayrünissa wore a headscarf and statements Gül had allegedly made in the 1990s as a member of the Islamist Welfare Party (Refah Partisi-RP) sufficed to declare his candidacy a threat for the Republic.

Civil society associations were soon also involved. On 14 April 2007, secularist associations organized a demonstration in Ankara to declare their determination to defend secularism and the spirit of the Republic. The demonstration, symbolically organized in front of Anitkabir, Atatürk's mausoleum, gathered big crowds and was followed by similar demonstrations in Istanbul on 28 April 2007, and Izmir and other smaller cities on 14 May 2007. Large turnouts manifested the divide within Turkish society. The millions of Turkish citizens who demonstrated in Ankara, Istanbul, Izmir and other cities in defence of the secular values of the Republic represented the middle-class elites of the country who felt threatened by the meteoric rise of the AKP, the further reinforcement of the party-affiliated conservative elite and its prospective control of both highest state offices. Despite repeated statements by the AKP about its commitment to the secular principles of the Republic and its comprehensive reform programme, they insisted that the government party was performing takiyye - and that there was a hidden agenda to Islamize the country. The unease of a large part of Turkey's middle class about the rise of the AKP was matched with severe bureaucratic and military reaction.

The political turmoil took the dimensions of a constitutional crisis when the military and civil bureaucracy took a clear position against the government. On 27 May 2007, the General Staff issued a statement which appeared on its website. In an intervention for which the neologism 'e-coup' was coined, the military listed a number of incidents which adopted the claims that a rising Islamist 
activity comprised a serious threat for the Turkish Republic and warned that the Turkish military would not remain indifferent to such a development.

During the last days, the problem which emerged in the Presidential election process has been focused on the debate of secularism. The Turkish Armed Forces follow this with concern. One should not forget that the Turkish Armed Forces are a party in these discussions and a definitive defender of secularism. The Turkish Armed Forces are definitively against the discussions and unfounded allegations made and, if necessary, will expose their stance and behaviour in an open and clear way ... The Turkish Armed Forces maintain their unshakeable decisiveness regarding the flawless implementation of their law-given duties to protect these features and maintains a firm belief in the binding character of this decisiveness. ${ }^{64}$

This direct political intervention of the military caused a major political crisis in a country with a long record of military coups. What made the situation worse was that the major opposition party, the secularist Republican People's Party (Cumhuriyet Halk Partisi - CHP) did not object to the military intervention into politics and its threats against the government but, on the contrary, seemed to endorse them. The situation was further aggravated on 1 May 2007. On that day, the Constitutional Court delivered a controversial opinion on the question of a quorum in the presidential elections, following an appeal by the CHP. The decision upheld the CHP's claim and made the election of an AKP-supported presidential candidate by the parliament impossible. While the legal basis of the decision was at best unsound, at the political level, this decision showed that the judiciary had in effect sided with the military in its opposition to the government party. The court decision stalled the presidential election process and led Prime Minister Erdoğan to call for early elections on 22 July 2007, as well as a constitutional referendum to establish the popular election of the president.

A tense election campaign came to an end with a triumphant victory for the incumbent AKP. With $46.7 \%$ of the vote, the government party scored a victory whose magnitude had been difficult to predict. Despite being in power for almost five years, the AKP increased its electoral appeal by more than $12 \%$ compared to the 2002 elections. This was the strongest proof that the party enjoyed the broad support of the public in its confrontation with the military and bureaucratic elites. By its vote, the Turkish people condemned the bureaucratic interventions and infringement of democratic practices. In fact, the sharp rise of the AKP's electoral strength could only be explained in terms of result of the political crisis. The polarizing effect of the military encroachment made many Turkish democratic citizens vote for the AKP, not because they approved of their political programme, but simply in order to protest against the military involvement.

Yet, more turmoil was to follow when the AKP government allied with the opposition Nationalist Action Party (Milliyetçi Hareket Partisi - MHP) to pass a constitutional amendment whose aim was to allow the use of the headscarf in university campuses. The CHP appealed against the amendment which was passed with a large majority in the Constitutional Court. The decision of the 
Constitutional Court to annul the amendment appeared to set an alarming precedent, reinforcing claims by intellectuals about the rise of a 'juristocracy', a regime where the sovereignty does not belong to the people or the parliament but to the judiciary. Meanwhile, in March 2008, the Chief Prosecutor Abdurrahman Yalçınkaya filed a closure case against the AKP accusing it of having become a 'centre of antisecular activity'. ${ }^{65}$ The court's decision in July 2008 adopted the argument of the prosecutor but fell short of closing the government party. Instead, it set its future political initiatives on secularism under judicial scrutiny. ${ }^{66}$

\section{Secularism and the fear of Turkey's Islamization}

The backdrop to the political crisis was an increasing apprehension in Turkey's secular class about an encroaching Islamization threat. Justified or not, this fear did have a significant impact on the attitudes of a sizeable part of the Turkish people. The electoral victory of the AKP in the 2002 elections marked a milestone in the rise of a new Islamist 'counter-elite'. A new generation of well-educated, Western-oriented, religious and conservative professionals, who first appeared in the 1980s, was taking control of the country's government for the first time. During AKP rule, they further strengthened their position within the state administration, despite the opposition of the Republic's secularist President Ahmet Necdet Sezer and the opposition of the country's military and state bureaucracy. The election of Abdullah Gül to the President's office meant the takeover by the AKP of the last secularist bastion in executive power. For the first time since the 1950 s, peripheral social forces which were hitherto marginalized in republican Turkish politics would assume control of the state. ${ }^{67}$ This upset the secularist elites who had seen their political and social influence waning alarmingly in recent years. Their major participation in the 'republic's demonstrations', a series of secularist, anti-AKP demonstrations organized throughout Turkey in spring 2007, manifested their unease at the new constellation of powers in the Turkish political system. It also underlined their fear about the sustainability of a secular way of living in an AKP-dominated Turkey. Despite being a numerical minority in Turkish society, they enjoyed a disproportionate influence upon Turkish politics. However, as a consequence of Turkey's democratization, their position became untenable. As Turkey was transforming into a democratic society, political power gradually shifted from the secularist elite to the conservative social majority, which was very successfully represented by the AKP. Fazıl Say's reaction, underlined at the beginning of this study, also mirrored the inability of many Turkish secularists to adapt to this new environment. Cemil İpekçi's response pointed directly to that.

Confusion about the ongoing Islamization of Turkish society did not leave academia unscathed. Conflicting information and opinion polls allowed academics to defend antithetical positions on the issue of the Islamization of Turkish society. Two major surveys published in late 2007 announced conflicting results on the headscarf issue, which had the effect of increasing still further public attention. 
The first survey argued that despite what many secularist Turks thought, the number of covered women as a percentage of the whole population had fallen. ${ }^{68}$ It was only their rising public visibility and the fact that they were freer now to commute and participate in public life that jointly created the impression that the use of the headscarf was increasing in Turkey. ${ }^{69}$ However, according to the second survey, there was a slight rise in the number of covered women as a percentage of the whole population. More significant though was the sharp rise of the percentage of women wearing the politically significant türban ${ }^{70}$ among the covered women. ${ }^{71}$ Fears about Turkey apparently impending Islamization were often linked to the transformation of the Turkish political Islam. Many secularists argued that Turkey was distancing itself from Europe and increasingly resembling Malaysia as an economically globalized but socially Islamic society. ${ }^{72}$ In addition, many scholars pointed to the lack of a liberal consensus in Turkey as the root of more general social mistrust and conflict. In what Şerif Mardin called the 'neighbourhood's pressure' (mahalle baskisl), ${ }^{73}$ Turkey's rising peripheral, conservative social class was attempting to impose its communitarian social values upon the secularist segment of the society. However, the core element of this stance, i.e. lack of respect for individual autonomy, did not pertain only to conservatives; it pervaded the whole of Turkish society. Thus the resolution of Turkey's deep social division on the issue of secularism remains inextricably linked with the rise of a liberal consensus which would allow the coexistence of different lifestyles. To this end, Turkey's EU membership could be of critical significance in terms of anchoring reform already made and triggering further liberalization.

\section{Conclusion}

Secularism has remained a focal point of Turkish politics throughout the history of republican Turkey. While Islamist political parties used to challenge secularism on Sharia-based arguments, the transformation of political Islam allowed for a liberal critique of Turkish secularism. The AKP advocated a version of secularism which would not ostracize manifestations of religious belief from the public sphere. Nonetheless, secularism remained a deeply divisive issue and led to consecutive political crises. Following his controversial election, President Abdullah Gül tried to convince everyone of the AKP government's commitment to the secular principles of the Republic. In his inauguration speech, he once more dismissed claims about the existence of a hidden Islamist agenda and added:

The Turkish Republic is a democratic, secular, social state, governed by the rule of law. These features established through the non-amendable stipulations of our constitution are a whole and each of them is undoubtedly a fundamental value of our Republic. I will always be determined and resolved to advocate, without discrimination, each of these principles and to further strengthen them at every opportunity. Secularism, one of our foundational principles is a rule of social peace, as well as a model which allows for different ways of life within democracy, a system based on law and freedoms. ${ }^{74}$ 
Many expected that both President Gül and Prime Minister Erdoğan would give clear political signals of their intentions to respect religious freedom and advocate a tolerant version of secularism. Yet the country again became embroiled in a bitter confrontation between the AKP government and the secularist establishment. The closure case against the AKP in March 2008 on the grounds of being a 'focal point of anti-secular activity' brought secularism once again to the main stage of Turkish politics. The judicial process highlighted deep social divisions within Turkey, as well as the urgency of a liberal reconfiguration of the country's political system. While the AKP was spared closure, the July 2008 decision confirmed the allegations of the Chief Prosecutor about its 'anti-secular activities'. It is plausible to argue that a redefinition of state-religion relations in Turkey, so that Muslims, non-Muslims, atheists and agnostics enjoy equal respect for their beliefs is a necessary condition of the AKP-advocated liberal version of secularism. The implementation of such a reform could prove the sincerity of AKP commitments and reduce social cleavages, sharply manifested since April 2007. What is clearly missing, however, is a high level of mutual trust between Turkey's conservatives and secularists. In a country where a liberal culture of mutual toleration and respect for individual autonomy is not fully-fledged and social trust is a scarce resource, an external actor such as the European Union seems to be the actor best suited to act as arbiter and facilitate trust-building. The reinvigoration of Turkey's European integration process could perhaps provide the best framework for the development of mutual respect for different lifestyles within a tolerant society.

\section{Notes}

1. Hermann, 'Der Paukenschlag Des Pianisten'.

2. Günay's statement was of special importance, as he was himself one of the centre-left secularist politicians who decided to join the ranks of the AKP on the eve of the July 2007 elections.

3. Mağden, Fazıl Say haksız mi?

4. Nişantaş is one of the most affluent, secularist boroughs of Istanbul.

5. Balta, 'Fazıl Say, Türkiye'yi Nişantaşı'ndan Ibaret Zannediyor'.

6. Ankara Bürosu, Türkiye 'Oh' dedi.

7. The prospect of the election of Abdullah Gül to the presidency of the country met with the fierce opposition of the secularist elite, because Gül's wife wears a headscarf. The publication of a military statement on the issue led to early elections in July 2007, which were won by the AKP by a wide margin.

8. Fuller, 'Turkey's Strategic Model: Myths and Realities', 52.

9. Gülalp, 'Whatever Happened to Secularization? The Multiple Islams in Turkey', 389-90.

10. On this, see Kuru, Reinterpretation of Secularism in Turkey: The Case of the Justice and Development Party.

11. This paradox was already observed in 1954 by Ali Fuat Başgil. See Başgil, Din ve Laiklik, 220, cited in Çakır and Bozan, Sivil, Şeffaf ve Demokratik Bir Diyanet İşleri Başkanlı̆̆ Mümkün Mü?, 107.

12. Kara, 'Diyanet İşleri Başkanlığı', 180-3.

13. This instrumental use of Islam, however, met with the opposition of Islamists. See Y1lmaz, 'Darbeler ve İslâmcilık', 637-9. 
14. Alevis are a syncretistic, heterodox Islamic group whose faith combines elements of Shiite Islam, Christianity, Shamanism and other Anatolian cultural heritage.

15. Göle, 'Secularism and Islamism in Turkey: The Making of Elites and Counter-Elites', 48-9.

16. Mahçupyan, 'Aleviler, Azınlık, Diyanet'.

17. Grigoriadis, Trials of Europeanization: Turkish Political Culture and the European Union, 105-7.

18. Toprak, 'Türkiye'de Laiklik, Siyasal İslam ve Demokrasi', 289.

19. Çarkoğlu and Toprak, Türkiye'de din, toplum ve siyaset, 17.

20. Grigoriadis, 'AKP and the Paradox of Islamic Europhilia', 66.

21. The National View (Milli Görüşs) movement was founded by Necmettin Erbakan in the late 1960s and became the focal point for the rise of Turkish political Islam.

22. Erbakan frequently juxtaposed European power (kuvvet) against Islamic justice (hak).

23. European Court of Human Rights (ECHR), Registrar's Press Release: Judgment in the Case of Refah Partisi (Welfare Party), Erbakan, Kazan and Tekdal vs. Turkey. The full text of the decision is available at European Court of Human Rights, Refah Partisi [Welfare Party] and Others vs. Turkey (No. 41340/98, No. 41342/98 and No. 41334/98): Third Section, 2001, http://cmiskp.echr.coe.int/tkp197/view. asp?action $=\mathrm{html} \&$ documentID $=697494 \&$ portal $=\mathrm{hbkm} \&$ source $=$ externalbydoc number\&table $=$ F69A27FD8FB86142BFO1C1166DEA398649.

24. European Court of Human Rights (ECHR), Refah Partisi [Welfare Party] and Others vs. Turkey.

25. Grigoriadis, 'AKP and the Paradox of Islamic Europhilia', 68.

26. For parallel developments in the field of tarikats and the Fethullah Gülen movement, see Yavuz, 'Towards an Islamic Liberalism? The Nurcu Movement and Fethullah Gülen', 600-5.

27. Fokas, 'The Islamist Movement and Turkey-EU Relations', 154-5.

28. Jenkins, 'Muslim Democrats in Turkey?', 53-5.

29. Çağaptay, 'The November 2002 Elections and Turkey's New Political Era', 44.

30. Yılmaz, 'İslâmcılık, AKP, Siyaset', 613-17; and Akdoğan, 'Adalet ve Kalkınma Partisi', 625-31. Dağ1 suggested the term 'post-Islamist' to explain the transformation of the AKP ideology. See Dağ1, 'Rethinking Human Rights, Democracy, and the West: Post-Islamist Intellectuals in Turkey'.

31. Heper and Toktaş, 'Islam, Modernity, and Democracy in Contemporary Turkey: The Case of Recep Tayyip Erdoğan', 173.

32. This was manifested in numerous opinion polls throughout the 2000s. Although public support for Turkey's EU membership fell significantly after 2005, it has not waned out.

33. Dağ Westernization', 31.

34. Grigoriadis, 'AKP and the Paradox of Islamic Europhilia', 67.

35. On the conservative nature of the AKP, see Aktay, Íslâmcılıktaki Muhafazakârlık Bakiye, 348-50.

36. Dağ 1 , 'Transformation of Islamic Political Identity in Turkey: Rethinking the West and Westernization'.

37. Cizre and Çınar, 'Turkey 2002: Kemalism, Islamism, and Politics in the Light of the February 28 Process', 327.

38. Grigoriadis, 'The First "Muslim Democratic" Party? - The AKP and the Reform of Political Islam in Turkey', 26-7.

39. See Kuru, Reinterpretation of Secularism in Turkey: The Case of the Justice and Development Party.

40. Assertive secularism is here used as a synonym of secularism. 
41. Akdoğan, AK Parti ve Muhafazakâr Demokrasi, 6.

42. Insel, 'The AKP and Normalizing Democracy in Turkey', 304.

43. See Alpay, 'AB, Türkiye ve İslam'.

44. On this, see Kuru, Reinterpretation of Secularism in Turkey: The Case of the Justice and Development Party.

45. Heper and Toktaş, 'Islam, Modernity, and Democracy in Contemporary Turkey: The Case of Recep Tayyip Erdoğan', 176.

46. Ali Bulaç is a primary example of this shift. His argument on the 'three generations of Islamist politics' is illuminating. See Bulaç, 'İslâm'ın Üç Siyaset Tarzı Veya İslâmcıların Üç Nesli', 48-50. See also Dağı, 'Rethinking Human Rights, Democracy, and the West: Post-Islamist Intellectuals in Turkey', 143-9.

47. Some authors even came to the point of discovering human rights courts during the Islamic ‘Era of Felicity'. See Şahin, ‘İslam'da Insan Hakları Mahkemesinden Bir Örnek!'.

48. Dağ 1 , 'Rethinking Human Rights, Democracy, and the West: Post-Islamist Intellectuals in Turkey', 141.

49. Bulaç, 'CHP, Anadolu Solu ve Başörtüsü'.

50. Dağ 1 , 'Rethinking Human Rights, Democracy, and the West: Post-Islamist Intellectuals in Turkey', 142.

51. Coşar and Özman, 'Centre-Right Politics in Turkey after the November 2002 Election: Neo-Liberalism with a Muslim Face', 66.

52. Heper and Toktaş, 'Islam, Modernity, and Democracy in Contemporary Turkey: The Case of Recep Tayyip Erdoğan', 160; and Belge, 'Takiye Tartışmasi'.

53. The short-lived proposal to penalize adultery during the reform of the Turkish Penal Code in August 2004 is a prime example.

54. See European Court of Human Rights (ECHR), Leyla Şahin vs. Turkey, 26. This decision came under heavy attack by European human rights organizations, which diagnosed a dangerous illiberal shift in the ruling of the court, following the emergence of a headscarf question in EU member states like France.

55. Many pious Turks thought that the ECHR was applying double standards against Islam. In any case the decision only ruled that headscarf restrictions in higher education did not violate the freedom of religion according to the ECHR. It neither justified nor posed any obstacles to the lifting of the restrictions themselves. See Akyol, 'Anayasa, Laiklik, Siyaset'.

56. Ankara Bürosu, Diyanet bütçesi 37 kurumu solladl.

57. See Çakır and Bozan, Sivil, Şeffaf ve Demokratik Bir Diyanet İşleri Başkanlı̆̆ı Mümkün mü?, 73-4. Nonetheless, the rise in the number of mosques should not only be attributed to increasing religiosity, but also to rising welfare.

58. Kara, 'Diyanet İşleri Başkanlı̆̆ı', 194-6.

59. Commission of the European Communities, 2004 Regular Report on Turkey's Progress towards Accession, 44-5.

60. Çakır and Bozan, Sivil, Şeffaf ve Demokratik Bir Diyanet Işsleri Başkanlığı Mümkün Mü?, 110-17.

61. Age-old Sunni prejudices of Alevi Islam survived in the AKP. A statement of Prime Minister Recep Tayyip Erdoğan spoke volumes about the level of intolerance on the Alevi issue among Sunni Muslims. When asked during a television interview on his opinion on the Alevi question he replied that Alevism is not a religion and added: 'If Alevism means to love Ali and follow his path, I am also Alevi. I am one of those who struggle to live like Ali. I am more Alevi than them.' See Soykan, 'Alevi Tepkisi Artıyor'. See also Erdem, 'Cemevi Sosyal Tesismiş'.

62. Grigoriadis, 'EU-Beitrittsprozeß Und Säkularismus in Der Türkei', 29.

63. Çakır and Bozan, Sivil, Şeffaf ve Demokratik Bir Diyanet İsleri Başkanlığı Mümkün Mü?, 336-9. 
64. Genelkurmay Başkanlığı, Basın Açılklaması (Ba-08/07) [Press Statement].

65. Ankara Bürosu, Yargıtay Başsavcısı AKP'nin kapatılmasını istedi.

66. Tahincioğlu, AKP'ye 'ciddi ihtar'.

67. On centre-periphery relations in republican Turkey, see the classical Mardin, 'CenterPeriphery Relations: A Key to Turkish Politics?'.

68. Çarkoğlu and Toprak, Religion, Society and Politics in a Changing Turkey, 62-9.

69. Istanbul Bürosu, 'Örtülü Kadın Azaldı Malezya Olmuyoruz!' ['Headscarved Women Decreased, we do not become Malaysia!'].

70. Women who wore the türban and not a simple headscarf expressed their dissidence against the secularist politics of republican Turkey.

71. Erdem, 'Gündelik Yaşamda Din, Laiklik ve Türban 1: Türbanın Hızlı Yükselişi'.

72. On this, see Mert, Türkiye ve Malezya.

73. Çakır, Şerif Mardin: Mahalle Baskist-Ne demek istedim.

74. Ankara Bürosu, '11. Cumhurbașkanı Abdullah Gül'ün TBMM Genel Kurulu'ndaki Konuşmasının Tam Metni: Özgürlük ve Laiklik Vurgusu' ['Full Text of the Speech of the 11th President of the Republic Abdullah Gul at the Turkish Grand National Assembly: Emphasis on Freedom and Securalism'].

\section{Note on contributor}

Dr Ioannis N. Grigoriadis is Assistant Professor at the Department of Political Science, Bilkent University. He completed his undergraduate studies at the University of Athens, where he studied Law. In 2002 he obtained a Master of International Affairs (MIA) and a Certificate of Middle Eastern Studies from the School of International \& Public Affairs (SIPA), Columbia University. In 2005, he earned a PhD in Politics at the School of Oriental and African Studies (SOAS), University of London. He has taught at Turkish universities (Sabanci University, Isik University) for three years. Between 2007 and 2009 he was Lecturer at the Department of Turkish and Modern Asian Studies, University of Athens. His research interests include European, Middle Eastern and energy politics, nationalism and democratization.

\section{Bibliography}

Akdoğan, Yalçın. 'Adalet ve Kalkınma Partisi'. In Íslamcılık, ed. Yasin Aktay, Modern Türkiye'de Siyasi Düşünce, 620-31. İstanbul: İletişım, 2004.

Akdoğan, Yalçın. AK Parti ve Muhafazakâr Demokrasi [AK Party and Conservative Democracy]. Ankara: AK Parti Yayınları, 2004.

Aktay, Yasin. 'İslâmc1lıktaki Muhafazakârlık Bakiye'. In Muhafazakârlık, ed. Ahmet Çiğdem, Modern Türkiye'de Siyasi Düşünce. İstanbul: İletişım, 2003.

Akyol, Taha. 'Anayasa, Laiklik, Siyaset' ['Constitution, Secularism, Politics']. Milliyet, April 27, 2007.

Alpay, Şahin. 'AB, Türkiye ve İslam' ['EU, Turkey and Islam']. Zaman, October 9, 2004.

Balta, İbrahim. 'Fazıl Say, Türkiye'yi Nişantaşı'ndan Ibaret Zannediyor' [Fazil Say thinks that Turkey consists of Nisantasi]. Zaman, December 16, 2007.

Başgil, Ali Fuat. Din ve Laiklik [Religion and Secularism], İkinci Baskı. ed. İstanbul: Kubbealtı Neşriyat, 2003.

Belge, Murat. 'Takiye Tartışmasi' ['The Debate about Dissimulation']. Radikal, November 8, 2002.

Bulaç, Ali. 'CHP, Anadolu Solu ve Başörtüsü' ['CHP, the Anatolian Left and the Headscarfs']. Zaman, July 3, 2002. 
Bulaç, Ali. ‘İslâm'ın Üç Siyaset Tarzı Veya İslâmcıların Üç Nesli’ ['Three Political Ways of Islam or Three Generations of Islamists']. In Íslamcllı, ed. Yasin Aktay. Modern Türkiye'de Siyasi Düşünce. İstanbul: İletişım, 2004.

Bürosu, Ankara. '11. Cumhurbaşkanı Abdullah Gül'ün TBMM Genel Kurulu'ndaki Konuşmasının Tam Metni: Özgürlük ve Laiklik Vurgusu'. Radikal, August 29, 2007.

Bürosu, Ankara. 'Diyanet Bütçesi 37 Kurumu Sollad?' ['The Directorate of Religious Affairs outmarched 37 Institutions']. Hürriyet, October 24, 2006.

Bürosu, Ankara. 'Türkiye “Oh” Dedi' ['Turkey says “Oh”']. Radikal, July 31, 2008.

Çağaptay, Soner. 'The November 2002 Elections and Turkey's New Political Era'. Middle East Review of International Affairs (MERIA) 6, no. 4 (2002): 42-8.

Çakır, Rusen. 'Şerif Mardin: Mahalle Baskısı-Ne Demek Istedim'. NTVMSNBC, May 28, 2008.

Çakır, Ruşen, and İrfan Bozan. Sivil, Şeffaf ve Demokratik Bir Diyanet Işsleri Başkanlığ Mümkün Mü? [Is a Civil, Transparent and Democratic Directorate of Religious Affairs Possible?] İstanbul: TESEV Yayınları, 2005.

Çarkoğlu, Ali, and Binnaz Toprak. Değişen Türkiye'de Din, Toplum ve Siyaset. İstanbul: TESEV, 2006.

Çarkoğlu, Ali, and Binnaz Toprak. Religion, Society and Politics in a Changing Turkey. Istanbul: TESEV, 2007.

Cizre, Ümit, and Menderes Çınar. 'Turkey 2002: Kemalism, Islamism, and Politics in the Light of the February 28 Process'. South Atlantic Quarterly 102, no. 2/3 (2003): 309-32.

Commission of the European Communities. 2004 Regular Report on Turkey's Progress Towards Accession [SEC(2004) 1201]. Brussels: European Union, 2004.

Coşar, Simten, and Aylın Özman. 'Centre-Right Politics in Turkey after the November 2002 Election: Neo-Liberalism with a Muslim Face'. Contemporary Politics 10, no. 1 (2004): $57-74$.

Dağı, İhsan D. 'Rethinking Human Rights, Democracy, and the West: Post-Islamist Intellectuals in Turkey'. Critique: Critical Middle Eastern Studies 13, no. 2 (2004): $135-51$.

Dağı, İhsan D. 'Transformation of Islamic Political Identity in Turkey: Rethinking the West and Westernization'. Turkish Studies 6, no. 1 (2005): 21-37.

Erdem, Tarhan. 'Gündelik Yaşamda Din, Laiklik ve Türban 1: Türbanın Hızlı Yükselişi'. Milliyet, December 3, 2007.

Erdem, Zihni. 'Cemevi Sosyal Tesismiş' ['Cemevis were Social Premises']. Radikal, May 1, 2005.

European Court of Human Rights (ECHR). 'Leyla Şahin vs. Turkey'. Strasbourg: Fourth Section, 2004.

European Court of Human Rights (ECHR). 'Refah Partisi [Welfare Party] and Others vs. Turkey'. Third Section, 2001.

European Court of Human Rights (ECHR). 'Refah Partisi [Welfare Party] and Others vs. Turkey'. Grand Chamber, 2003.

European Court of Human Rights (ECHR). 'Registrar's Press Release: Judgment in the Case of Refah Partisi (Welfare Party), Erbakan, Kazan and Tekdal vs. Turkey’. Strasbourg, 2001.

Fokas, Effie. 'The Islamist Movement and Turkey-EU Relations'. In Turkey and European Integration: Accession Prospects and Issues, ed. Mehmet Uğur and Nergis Canefe. London \& New York: Routledge, 2004.

Fuller, Graham E. 'Turkey's Strategic Model: Myths and Realities'. Washington Quarterly 27, no. 3 (2004): 51-64.

Genelkurmay, Başkanlığı. 'Basın Açıklaması (Ba-08/07)'. Ankara: Genelkurmay Başkanlığı, 2007. 
Göle, Nilüfer. 'Secularism and Islamism in Turkey: The Making of Elites and CounterElites'. Middle East Journal 51, no. 1 (1997): 46-58.

Grigoriadis, Ioannis N. 'AKP and the Paradox of Islamic Europhilia'. Turkish Policy Quarterly 3, no. 1 (2004): 65-70.

Grigoriadis, Ioannis N. 'EU-Beitrittsprozeß und Säkularismus in der Türkei' [Turkey's EU Accession Process and the Question of Secularism]. Südosteuropa Mitteilungen 47, no. 2 (2007): 20-31.

Grigoriadis, Ioannis N. 'The First "Muslim Democratic" Party? - The AKP and the Reform of Political Islam in Turkey'. In Moderate Islamists as Reform Actors: Conditions and Programmatic Change, ed. Muriel Asseburg. Berlin: Stiftung Wissenschaft und Politik, 2007.

Grigoriadis, Ioannis N. Trials of Europeanization: Turkish Political Culture and the European Union. New York, NY: Palgrave Macmillan, 2008.

Gülalp, Haldun. 'Whatever Happened to Secularization? The Multiple Islams in Turkey'. South Atlantic Quarterly 102, no. 2/3 (2003): 381-95.

Heper, Metin, and Toktaş Şule. 'Islam, Modernity, and Democracy in Contemporary Turkey: The Case of Recep Tayyip Erdoğan'. Muslim World 93, no. 2 (2003): 157-85.

Hermann, Rainer. 'Der Paukenschlag Des Pianisten' ['The Drumbeat of the Pianist']. Frankfurter Allgemeine Zeitung, December 18, 2007.

Insel, Ahmet. 'The AKP and Normalizing Democracy in Turkey'. South Atlantic Quarterly 102, no. 2/3 (2003): 293-308.

Istanbul, Bürosu. ‘Örtülü Kadın Azaldı Malezya Olmuyoruz!' Radikal, September 28, 2007.

Jenkins, Gareth. 'Muslim Democrats in Turkey?' Survival 45, no. 1 (2003): 45-66.

Kara, İsmail. 'Diyanet İşleri Başkanlığı' ['Directorate of Religious Affairs']. In İslamcılık, ed. Yasin Aktay, Modern Türkiye'de Siyasi Düşünce. İstanbul: İletişım, 2004.

Kuru, Ahmet T. 'Reinterpretation of Secularism in Turkey: The Case of the Justice and Development Party'. In Transformation of Turkish Politics, ed. M. Hakan Yavuz. Salt Lake City: University of Utah Press, 2006.

Mağden, Perihan. Fazıl Say Haksız mı? ['Is Fazil Say Wrong?'] Radikal, December 16, 2007.

Mahçupyan, Etyen. 'Aleviler, Azınlık, Diyanet' ['Alevis, Minority, Directorate of Religious Affairs']. Zaman, November 1, 2004.

Mardin, Şerif. 'Center-Periphery Relations: A Key to Turkish Politics?'. Daedalus 102, no. 1 (1973): 169-90.

Mert, Nuray. 'Türkiye ve Malezya'. Radikal, October 2, 2007.

Şahin, Ahmet. 'İslam'da Insan Hakları Mahkemesinden Bir Örnek!' Zaman, December 14, 2004.

Soykan, Timur. 'Alevi Tepkisi Artıyor'. Radikal, October 9, 2004.

Tahincioğlu, Gökçer. 'AKP' ye "Ciddi Ihtar"' ['Serious Warning to the AKP']. Milliyet, July 31, 2008.

Toprak, Binnaz. 'Türkiye'de Laiklik, Siyasal İslam ve Demokrasi' ['Secularism, Political Islam and Democracy in Turkey']. Uluslararasi Atatürk ve Cağdaş Toplum Sempozyumu, ed. Demokrasi ve Gençlik Vakfı. İstanbul: İş Bankası Kültür Yayınları, 2002.

Yavuz, M. Hakan. 'Towards an Islamic Liberalism? The Nurcu Movement and Fethullah Gülen'. Middle East Journal 53, no. 4 (1999): 584-605.

Yılmaz, Murat. 'Darbeler ve İslâmcilık' ['Coups and Islam']. In İslamcllık', ed. Yasin Aktay, Modern Türkiye’de Siyasi Düşünce. İstanbul: İletişım, 2004.

Y1lmaz, Nuh. 'İslâmcıllk, AKP, Siyaset'. In İslamcılık, ed. Yasin Aktay, Modern Türkiye'de Siyasi Düşünce. İstanbul: İletişım, 2004. 